\title{
Teaching all students: A holistic and collaborative approach to increasing student success
}

\author{
Veronica Udeogalanya \\ Department of Economics and Finance \\ Medgar Evers College, City University of New York, USA
}

\begin{abstract}
Keywords
Academic Success, Graduation Rates, Students, Teaching, Undergraduate Education.
\end{abstract}

\begin{abstract}
All students who enroll have success as their main goal. However, most institutions focus their resources on programs for students on honor roll, Dean's list and those progressing academically. Little resources remain for those students who stumble. In 2015, 36.2\% of white students, $22.5 \%$ of black students, and $15.5 \%$ of Hispanic students had completed four years of college. This shows a $13.7 \%$ gap between black and white students and a $20.7 \%$ gap between Hispanic and white students. How do we close this gap in educational completion? If we believe that all students can learn, there needs to be educational equity and the development of a framework for instruction and assessment of all students' learning outcomes. This paper represents an exploratory fundamental and qualitative research that aims to present a refocus on the role of faculty in teaching and learning to reach all students in classrooms. This paper examines a holistic and collaborative approach to increasing student success using evidence -based qualitative analysis of best practices. This approach has four component parts. Part 1 is the Holistic Component that involves engaging all students in the institution; communicating purposefully to them in a timely manner; and providing all-inclusive comprehensive support services (HC). This part develops and implements measurable benchmarks that motivate, encourage, and enable all students. Part 2 is the Collaborative Component which involves bringing six working teams together: faculty, industry, current majors, alumni, career services, and the community (CC). This part engages the team in maintaining a living curriculum that reflects the ever-changing global economy. Part 3 is Celebration of Student Success (CSS) which entails the collaborative team owning each milestone, reaffirming teamwork while building trust and persistence. Part 4 is the Assessment of Student Progress (ASP) using the holistic and collaborative approach. The paper concludes that holistic and collaborative teamwork that includes, respects, and empowers all students is the key to reducing the college completion gaps that exist among blacks and Hispanic students.
\end{abstract}

\section{Introduction}

Student success is a crucial component of higher educational institutions and has been an essential criterion for assessing the quality of student outcomes. There have been several definitions of student success in the literature (Kuh et al. 2006). Also, the concept of academic success has generally been associated with the attainment of summative assessments, as stipulated by learning outcomes. However, York et al. (2015) argue that the meaning of this term is debatable as it has an 'amorphous' identity, depending on varying subjective perspectives. Indeed, while academic success can be attributed to the attainment of knowledge demonstrated through high assessment grades, it can also refer to the graduates' capacity to secure a professional role related to their degree. After analyzing the literature on the use of this terminology in different subject fields, York et al. identify six elements which define it namely: academic achievement, engagement in educationally purposeful activities, satisfaction, acquisition of desired knowledge, skills and competencies, persistence, attainment of educational outcomes, and postcollege performance (p. 5). Furthermore, Education Data Mining (EDM) has been used for predicting a variety of crucial educational outcomes such as performance, success, satisfaction, and achievement (Calvet Llinan \& Juan Perez, 2015; Dutt et al. 2017; Anoopkumar \& Rahman, 2016; Martins et al. 2019; Willems et al. 2019). Despite all these publications, it is still difficult for faculty to effectively apply known techniques to specific academic problems. How can faculty better predict academic success of their 
students? Some researchers believe that the creation of a systematic process, where all related choices and constraints are comprehensively analyzed for improvements is the key. What is the role of faculty in the creation of such a systematic process that focuses on all enrolled students? How can such a system provide faculty with consistent information that monitors their student progress and unique challenges faced by the different groups of students? Research shows that the answer may lie in the development of a comprehensive database (Hamoud et al., 2018) addressing practical and measurable strategies in both academic success(retention and graduation) and the acquisition of soft skills that can advance student success.

All students who enroll have success as their main goal. However, most institutions focus their resources on programs for students on honor roll, dean's list and those progressing academically. Little resources remain for those students who stumble. In 2015, 36.2\% of white students, $22.5 \%$ of black students, and $15.5 \%$ of Hispanic students had completed four years of college. This shows a $13.7 \%$ gap between black and white students and a $20.7 \%$ gap between Hispanic and white students. How do we close this gap in educational completion? If we believe that all students can learn, there needs to be educational equity and the development of a framework for instruction and assessment of all students' learning outcomes. This paper developed a four-part holistic and collaborative approach to increasing student success using evidence -based qualitative analysis of best practices. Part 1 is the Holistic Component that involves engaging all students in the institution; communicating purposefully to them in a timely manner; and providing an all-inclusive comprehensive support services (HC). This part develops and implements measurable benchmarks that motivate, encourage, and enable all students. Part 2 is the Collaborative Component which involves bringing six working teams together: faculty, industry, current majors, alumni, career services, and the community (CC). This part engages the team in maintaining a living curriculum that reflects the ever-changing global economy. Part 3 is Celebration of Student Success (CSS) which entails the collaborative team owning each milestone, reaffirming teamwork while building trust and persistence. Part 4 is the Assessment of Student Progress (ASP) using the holistic and collaborative approach. The paper concludes that holistic and collaborative teamwork that includes, respects, and empowers all students is the key to reducing the college completion gaps that exist among blacks and Hispanic students. In addition, based on the sub-theme of this year's conference "Rethinking Business Education" this paper believes that faculty can teach all students by building trust in the classroom and modeling trustworthiness in their relationships with students. This is because all students need to be trained to participate in the labor market not just the most brilliant.

The rest of this paper consists of five sections. Section 2 reviews some of the literature on student success that informed this author. Then, section 3 presents the methodology implemented. Section 4 explains the model developed for achieving increasing academic success for all enrolled students. Section 5 discusses the various strategies mentioned. Finally, section 6 concluded this paper and suggests possible future work.

\section{Literature Review}

This paper reviewed several researches on college students' success, the challenges low-income students face to succeed in college, and the support mechanisms in place for them to overcome these challenges. This paper shows that there has also been an immense number of literature and research highlighting the relationship between faculty - student relationships and increases in academic success. Moreover, the growing body of research concerned with faculty effectiveness has reinforced the notion that specific characteristics and behaviors matter in teaching, in terms of student achievement and other desirable outcomes (Muijs et al., 2011). Wilson et al., 2015 focused on the teacher-mentor-adviser model by highlighting the role of student-faculty interactions, making student's discovery of knowledge pivotal instead of being receptacles of knowledge. The emphasis here is on rethinking modes of teaching by faculty as well as building innovative teaching into tenure and promotion decisions. Linking teaching effectiveness to student outcomes assessment and focusing on mastery to evaluate learning; all the time maintaining consciousness of own academic responsibilities and progress. Perez et al., 2014 emphasized the positive effects of explicit incorporation of identity development within faculty pedagogical process by focusing students on their own personalized learning processes. By so doing, faculty can engage students deeply in their content. They cautioned faculty not to assume that the students will self-navigate 
to available services and are able to maximize the use of what is available to them. They further argue that this is a costly assumption and Purdie and Rosser, 2011 advocated intentionally linking available student support services to the classroom through communication. Furthermore, Maton et al., 2016 focused on the power of integrating community-building experiences with student campus experiences by inviting key campus stakeholders, professional in the relevant fields to visit the classrooms. Only about 35 percent of first-time, full-time college students who plan to earn a bachelor's degree reach their goal within 4 years; 56 percent achieve it within 6 years (Adelman, 2006). For these and related reasons, the American College Testing Program (2006) declared that the nation has "a college readiness crisis." Also, student engagement is another indicator of student success that has received considerable attention in recent years (kuh 2006; Hurtado et al. 2012). A substantial body of research indicates that once students start college, a key factor to whether they will survive and thrive in college is the extent to which they take part in educationally effective activities. In this this paper, student success is defined as academic achievement, engagement in educationally purposeful activities, satisfaction, acquisition of desired knowledge, skills and competencies, persistence, attainment of educational objectives and post college performance in the world of work.

A further review of the research shows that only 21 percent of African American high school graduates, 33 percent of Hispanics, and 33 percent of students from families with annual incomes below $\$ 30,000$ have college-level reading skills (ACT 2006). Underrepresented populations have lower odds of completing high school and enrolling in college (Hearn 2006; Estrada et al. 2016). The high school completion rates of African Americans (77 percent) and Latinos (57 percent) trailed Whites (82 percent). Latino and African American college participation rates were equal at 35 percent, whereas the White participation rate was 43 percent (Finley et al. 2013). Bauman et al. 2005 reported a similar pattern for African American students, who are more likely to attend public high schools with high minority concentrations from low socioeconomic communities. Enrollment and graduation rates suggest that the odds are stacked against first-generation students succeeding in college (Baum and Payea 2004). Forty percent of first- generation students score in the lowest quartile of ACT or SAT (ACT 2006). They are also more likely to enroll at public universities and attend part time (ACT 2006) and were twice as likely to take remedial courses (21 percent vs 10 percent) after controlling for high school rigor (Astin 1993). A rigorous high school curriculum can narrow the college persistence gap for first-generation students (Dadgar et al. 2013) especially if they graduate high school in the top quartile. These students perform pretty much like other students in terms of their college grades (3.0 to 3.1 GPA) and remedial coursework (only 4-5 percent take such course). But on balance, even after controlling for socioeconomic status, institution type, and enrollment patterns, first generation status still has a negative effect on degree completion. For this host of reasons, no wonder first generation college students are more likely to drop out (73 percent to 60 percent) or to stop out of college for a period of time (19 percent to 8 percent) (Dadgar et al. 2013). First generation status also has a negative influence on pursuing a doctoral degree (Chen 2015). African American males and females remain underrepresented in most doctoral programs, especially in the sciences and engineering (Brame 2019). Students' chances of obtaining a postbaccalaureate degree appear to be enhanced by interactions with faculty, academic achievement, and academic involvement (Freeman et al. 2007).

This paper concurs with these researchers that faculty play a key role in student persistence. However, many of these researchers believed that if these gaps continue, educational attainment for African Americans and Latinos in the United States could actually further decline over the next 15 years if we are unable to close such gap between education levels of whites and other racial and ethnic populations (National Center for Public Policy and High Education 2005). These low participation rates may explain why college dropout rates of certain racial, ethnic, and socioeconomic groups remain relatively high. Persistence studies tend to focus on institutional factors and programs that promote continuous student enrollment. However, a key factor is the effort students put forth, especially the amount of time they spend studying (Astin 1993; Bailey and Leinbach, 2005). As noted earlier, first generation students are less likely to graduate because they earn fewer credits in their first year, take more remedial courses, are more likely to repeat courses, tend to major in vocational and technical fields, are less likely to choose a major in the first year of college (Asif 2015), and are less likely to live on campus 
(Reardon 2011). In addition, gift aid in the form of scholarships and grants and work-study as contrasted with loans are associated with higher retention and graduate rates (Reardon 2013), especially for lowincome and minority students. Fifty-five percent of students who receive financial aid persist, which is greater than nonrecipients and about even when controlling for academic ability (Hearn 2015). Grants have a strong effect on low-income and minority student's performance. Providing an African American or Hispanic student with an additional $\$ 1,000$ in grant funds decreased the probability of dropping out by 7 percent and 8 percent respectively (Hearn 2015).

Institutions in predominantly low-income neighborhoods show more positive impacts. Another challenge that too many students, especially those from historically underserved backgrounds face, is the lack of accurate information about postsecondary options. Most of them are confused about expectations for academic work, actual tuition costs, and the content of college entrance and placement tests (Valant et al. 2016). High school graduates that eventually go on to some form of postsecondary education sort themselves into five types of institutions; 2-year colleges (46 percent), public 4-year colleges (26 percent), private 4-year colleges (15 percent), for-profit entities (10 percent), and other types of schools (3 percent).Also, research consistently shows that delaying postsecondary enrollment, for whatever reason, reduced the likelihood that the student will persist and complete a degree program (Adelman 2006). African American and Hispanic community college students are also less likely to earn baccalaureate degrees because they are overrepresented in certificate programs (Bailey et al. 2015). As Pascarella and Terenzini $(2005$, p. 602) concluded, " the impact of college is largely determined by individual effort and involvement in the academic, interpersonal, and extracurricular offerings on a campus." As stated earlier, most students lack critical information that they need. In addition, intentional programs to facilitate student- faculty interaction have different effects on students. For example, relationships with faculty predicted development of academic competence among new students in the first year of college (Reason, Terenzini, and Domingo 2006), and sophomore success (in terms of GPA and satisfaction) was related to high-quality student-faculty interaction.

On balance, student persistence and success are related to the extent to which students interact with supportive adults on campus, both inside and outside the classroom (Kuh 2016 Pascarella and Terenzini 2005). For some purposes, occasional contact with faculty members may be enough. To illustrate, three of the six behaviors on the NSSE student-faculty cluster are of this kind: discussing career plans, working with a faculty member outside of class on a committee or project, and doing research with a faculty member. For most students, doing the first two of these once or maybe twice a semester is probably good enough. Working on a research project with a faculty member just once during college could be a lifealtering experience. For other activities, such as getting prompt feedback, discussing grades and assignments, and discussing ideas outside of class, the more frequent the contact the better (Kuh et al. 2013). Widespread use of effective pedagogical practice must be at the core of any agenda to promote student success. This area of research received more attention than any other over the past dozen years (Pascarella and Terenzini 2005), fueled by the expanding research and theory on human learning (National Center for Public Policy and High Education 2005). In the final analysis, student-faculty interaction is important because it encourages students to devote greater effort to other educationally purposeful activities. Both the nature and frequency of the contacts matter (Center for Community College Student Engagement 2013). Bailey and Leinbach (2005) and Bauman et al. (2005) offer further evidence of how institutions can organize their resources and create success-oriented cultures. Also relevant is emerging research associated with the ongoing Building Engagement and Attainment of Minority Students (BEAMS) project, Association of American Colleges and Universities' (AAC\&U) Making Excellence Inclusive initiative, Creating Role Models for Change A Survey of Tribal College Graduates (2000), and Diversity Scorecard (Bensimon et al. 2016), and the work of Hurtado et al. (2012), on the value of diversity and inclusion of underrepresented populations in higher education. However, if the students do not understand why such interactions are necessary, they may not appreciate them.

In addition, institutions that foster student success provide stimulating classroom experiences that encourage them to devote more time and effort to their learning and help them develop good study habits (Kuh et al. 2006; Valant et al. 2016). It is particularly important for institutions to invest in academic support services designed for the needs of diverse students (Bailey and Leinbach 2005), and for student 
and academic affairs to work together to improve the learning climate in and outside the classroom to have the greatest impact on student success. Pascarella and Terenzini (2005) concluded that attending college clearly influences occupations and earnings and various indices of quality of life, in part because college graduates tend to choose environments with similarly educated people, including spouses, close friends, and colleagues who share their social and political points of view. These quality of life benefits are transmitted to their children, favorably shaping their academic preparations, college-choices ad college performance. Furthermore, Pascarella and Terenzini (2005) found that students become more critical, reflective, and sophisticated thinkers during their college years and that college significantly enhances their general intellectual and analytical skills, critical thinking, and intellectual flexibility. To improve postsecondary preparation and success rates in an increasingly mobile society, a coordinated effort is required involving communities, k-12 schools, postsecondary institutions, and local and state business leaders and government officials, and policymakers (Zumbrunn et al. 2014). However, stereotype threat has its negative impact on academic achievement (Strayhorn 2015). These affective consequences can jeopardize successful task completion (Thelin 2011). Zumbrunn et al, 2014 and Brame, 2019 highlighted the provision of a conducive classroom environment that include motivational factors that predict student engagement and academic success. They believe that a supportive classroom climate leads to an increase in students' sense of belonging which in turn leads to an increase in academic success. Schinske et al, 2016 talked about identity-safe classroom environment built into the curriculum. They stated that intentionality toward interest in and respect for students in the class has a positive correlation with increase in cognitive capacity, persistence and academic success. This they maintain ensures that all students' contributions are heard and valued. Also, according to Dewsbury 2017 effective instructor-student dialogue engages all students and guarantees academic success.

Another aspect of the literature is on the shortfall of college graduates compared to the availability of highly skilled job vacancies. Research shows that if current trends continue in the production of bachelor's degrees, a 14 million shortfall of college-educated working adults is predicted by the year 2020 (Finn et al. 1997). The bad news is the enrollment and persistence rates of low-income students; African American, Latino, and Native American student ; and students with disabilities continue to lag behind White and Asian students, with Latino student trailing all other ethnic groups (Haak et al. 2011; Henderson 2008). Far too many students are falling short of their potential. Just over half (51 percent) of high school graduates have the reading skills they need to succeed in college (American College Testing Program (ACT) 2006). This latter fact is most troubling as 70 percent of students who took at least one remedial reading course in college do not obtain a degree or certificate within 8 years of enrollment (Adelman 2006).

College costs continue to increase faster than family incomes. From 1990 to 2000, tuitions rose at private universities by 70 percent, at public universities by 84 percent, and at public 2-year colleges by 62 percent (Reardon 2011, 2013). Those hit hardest by cost increases can least afford it. Charges at public institutions increased from 27 percent to 33 percent between 1986 and 1996 for families in the bottom quartile, but only from 7 percent to 9 percent for families in the top income quartile. This means for each $\$ 150$ increase in the net price of college attendance, the enrolment of students from the lowest income group decreases by almost 2 percent. Because tuition and fees have been rising faster than family income, there are also more students today with unmet financial need (Reardon 2011). Economic inequality now exceeds racial inequality in its impact on educational outcomes, although the effects of both remain significant. This shift became evident in the early part of the $21^{\text {st }}$ century, and it affects faculty today (Reardon, 2011, 2013). According to Reardon, 2013, Americans are more concerned about, and more supportive of policy initiatives that close wealth-based achievement gaps. Valant \& Newark, 2016 consider education as a great equalizer and since faculty have the greatest in-school impact on student academic success, investing in faculty development and student services can help to successfully address opportunity gaps. In addition, Finley et al. 2013 stated that if all black students were assigned to highly effective faculty four years in a row, this would be sufficient to close the average black-white achievement gap. They concluded that faculty have a powerful, long-lasting, life-changing influence on their students. Faculty directly affect how students learn, what they learn, how much they learn, and ways in which they interacted with one another and the world around them. 
Goffee and Jones, 2000 stated that "real faculty empathize fiercely with their students and care intensely about their student's work. They are also empathetically 'tough.' This means giving the students not necessarily what they want, but what they need to achieve their best". They practice what is called a tough empathy pedagogy. Teaching with tough empathy is not a soft pedagogy. It is an education principle that requires teachers to give students what they need, not what they want. At best, this method of instruction respects where students are in relation to the task they are asked to complete. The most effective teachers teach with a tough empathy pedagogy using the following three guidelines to implement their pedagogy, hold students to high expectations, listen to students with a desire to understand, not ridicule, never give up on students. These faculty that practice a tough empathy pedagogy need to bring their colleagues into the fold. The benefits will surely have a positive influence on your teaching and prepare their students for future success. Academic success has been attributed to student factors as well as teaching factors in the literature. Asif et al. 2017 consider psychological factors, beyond intellectual ability, to have an impact on academic achievement. Through the application of personality testing, these authors conclude that there are significant differences in personality between students with high attainment and those with low attainment. Participants' test scores on assertiveness, conscientiousness and emotionality correlated significantly with their grades, establishing that students' interpretation of their learning experience can lead to different academic results. Moreover, Kuh et al. 2006 assert that the students' learning style and achievement motivation relate to their academic success, showing that individual characteristics play an important role.

Bauman et al. (2005) highlighted the need for faculty to enhance a growth mindset in students. They also felt that an internal locus of control and making sure that university settings encourage the development of intrinsic motivation in students. Hence, responsibility is placed on the educators to instruct and instill development of these abilities, through purposely included aspects of the curriculum. Assessments are a compulsory component of university programs, having both a formative and summative function. Practical tasks with clearly communicated usefulness are more effective in preparing students for employment, rather than traditional assessment methods, such as examinations (York et al. 2015). Students perceive assessments as beneficial to their learning if they are explicitly aware of how they build on their current skill set and their relevance to their future career (Cachia et al. 2018). This therefore leads to the understanding that students are more likely to engage in the learning process if they can relate the set assignments to their employment ambitions. This is why we stated earlier that it is critical for faculty to clearly explain to students why they are doing the various assessments that each course requires. This paper is in concurrence with the "deep teaching model" enunciated by Dewsbury 2019 who emphasized a respectful classroom climate. We also agree with Thelin 2011 who emphasized the implementation of a progressive pedagogical technique leveraging the power of the community. And offers an approach for a model student success program. According to Haak et al 2011, faculty should emphasize a pedagogy of reflective personalized learning by acknowledging students' agency in learning and supporting a pedagogical structure that help students succeed thereby giving them a voice. They contend that it is important to develop meaningful dialogue with students by first seeking to know their students, forging lasting bonds and building meaningful learning experiences. The impact of how faculty teach and how students learn as well as who we teach and how we teach is at the center of this study. In addition, using innovations in pedagogies and teaching - related technology to tie assessment of educational outcomes for student learning with changes in the curriculum and institutional design and delivery is highly recommended. Along this line of thought, Witham et al. 2015 suggested that faculty must take into account the unique needs and characteristics of their students.

\section{Methodology}

This paper represents an exploratory fundamental and qualitative research that aims to present a refocus on the role of faculty in teaching and learning to reach all students in classrooms. It examines what can be done in order to increase student skills and preparedness. The analysis of the study is based on secondary data and sourced from existing literature and best practices. The objective was to ascertain the effectiveness of a holistic and collaborative approach to increasing student success. As institutions of higher education refocus their efforts on improving educational outcomes for students, this paper examines ways to increase the academic success of all enrolled students not just those on the presidents, 
deans, or honors programs. What is faculty contribution to socially disconnected classroom environments? How can we find a balance between faculty ownership of effective teaching and student academic performance and sense of belonging? In this paper we focused on identifying possible solutions to teaching all our enrolled students. The study questions that guided the development of our model were: How do students define academic success? What factors do they perceive as facilitators of such academic success? This paper presents a preliminary phase of this work, as this study progresses in the future, we will develop a two-stage qualitative design, with peer observations and informal interviews focusing on their pedagogical patterns and classroom practices. The first stage of the study will be to identify successful strategies and practices faculty can implement to teach all the enrolled students in their institution and increase their academic success. The next stage will be to identify components of the model that worked and those that did not on student academic success and the role of faculty in increasing the number of students who succeed in their academic pursuit. In the process of the research study, we were able to develop a model which we present here.

\section{The Model}

This paper believes that faculty can effectively teach all students enrolled in the colleges by using a holistic and collaborative approach to increasing student success. To this end, the paper developed a model that can help in achieving this goal. This approach has four component parts. Part 1 is the Holistic Component that involves engaging all students in the institution (those needing remediation, regular students navigating the college-level work, student achievers on honor roll/dean's list/president's list); communicating purposefully to them in a timely manner; and providing an all-inclusive comprehensive support services (HC). This part develops and implements measurable benchmarks that motivate, encourage, and enable all students. Part 2 is the Collaborative Component which involves bringing six working teams together: faculty, industry, current majors, alumni, career services, and the community (CC). This part engages the collaborative team in maintaining a living curriculum that reflects the everchanging global economy. For faculty to engage in a living curriculum, they must remain current. The intrinsic and extrinsic factors are highly interrelated for both faculty and students. For instance, the teaching provision allows for the practice and development of the faculty to guarantee currency. As for the students, there must be intentionality in building the personal skills required to achieve academic success. Inviting input in the curriculum from the external stakeholders in the collaborative team. For the industry it means bridging practice and theory thus strengthening the curriculum. Part 3 of the model is Celebration of Student Success (CSS) which involves the collaborative team owning each milestone achieved by their students, reaffirming teamwork while building trust and persistence at each stage. Finally, Part 4 is the Assessment of Student Progress (ASP) using a holistic and collaborative approach.

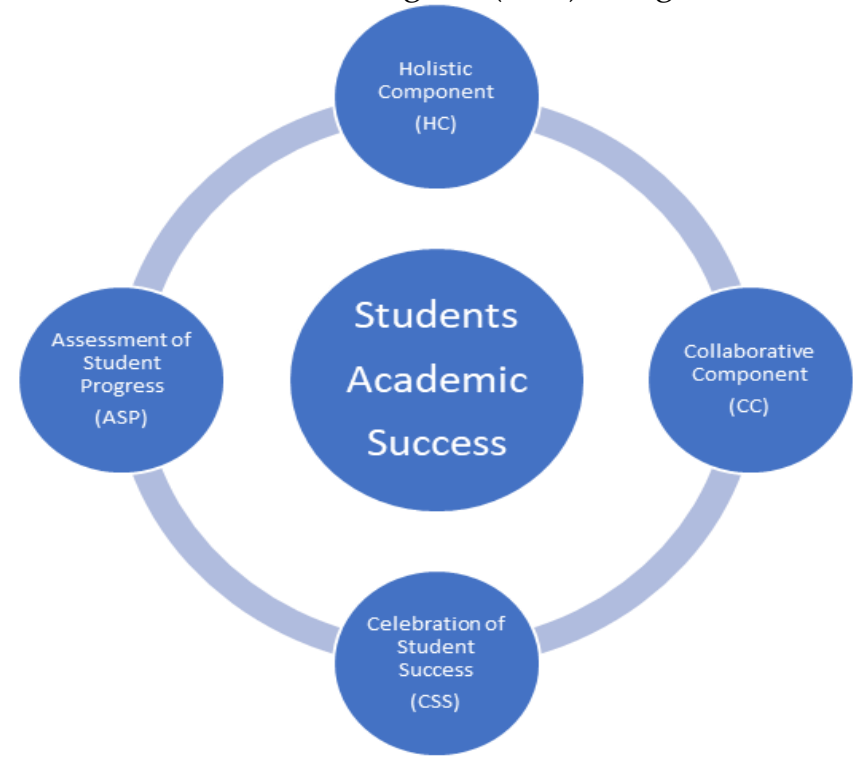




\section{Discussion}

Student success plays a dynamic role in higher education as most stakeholders' push for increase in rate of retention and graduation. Students enroll into colleges and universities with great expectations of academic success. Research show that these expectations can be achieved (Perez et al., 2014; Dewsbury, 2017). Decreasing higher education funding has placed real constraints on what institutions can do to respond to these expectations. Consequently, as a result of persistent increases in global economic crisis, increasing the academic success rate of students in colleges and universities in the United States is one of the greatest challenges facing higher education today. To increase student enrollment, institutions of higher education continue to search for innovative ways to do more with shrinking funding. This is because doing nothing is not an option and the real possibility of threats of faculty layoffs and/or faculty hiring freeze exacerbates the challenges. Continuous decline in student enrollment makes the challenges of colleges and universities more urgent. Most institutions are now at the point of reviewing what can be done. Many have begun looking within to rethink and repurpose many of their academic programs and activities. One of the most reviewed aspects of colleges and universities has focused on teaching and learning. Emphasis is on assessment of how faculty teach and how students learn focusing on who we teach and how we teach using innovations in pedagogies as well as teaching-related technology (Mohamed et al. 2017; Hamoud et al. 2018). Some of these studies suggests that retraining and retooling academic operations and processes encourages change. Most of the suggestions include academic program realignments, program mergers, shorter degree programs, accelerated courses, major shifts in course offerings, double majors, increases in job placements, provisions of certification programs. These researchers maintain that these suggested activities can help increase student academic success.

This paper concurs with these suggestions and draws attention to the impact of actions such as applying the holistic and collaborative teamwork that includes, respects, and empowers all students is the key to reducing the college completion gaps that exist among blacks and Hispanic students. Students' perception of what contributes to their academic success may differ from faculty's perceptions. Research has increasingly shown that a supportive classroom climate increases students' sense of belonging and increases academic success (Schinske et al., 2016). They emphasize identity-safe classroom where faculty engage with student voices and acknowledge student agency in learning. Brame, 2019 and Zumbrunn et al., 2014 are among researchers who encourage the intentionality of making students feel welcome, respected, and valued in classrooms. The paper further suggests that to be an effective faculty, an instructor needs to remain current with global changes. Education and teaching need to continue to evolve. Specifically, this model recommends using innovative assessment metrics that are more suited to today's education environment. Faculty are increasingly encouraged to think outside the box by designing assessment metrics that measure flexible learning; meeting the students where they are; breaking assignments into chunks and measuring them; rethinking high and low stakes tests that demonstrate student mastery of learning; promoting classroom assessment techniques that enhance learning through innovation; and ensuring both formative and summative assessment metrics. This paper's model encourages collaboration among schools, departments, academic programs to build and leverage synergies and continually review existing programs that eliminate duplication of activities thereby minimizing student frustrations.

As we focus in this paper on how faculty can teach all of our students, we must also discuss the institutional policy that encourage faculty to excel in teaching and learning. In framing the question of faculty embracing their student outcomes with pride, we must engage students to define their understanding of academic success by providing avenues for exploration, and opportunities for planning of how they can achieve their goals throughout their time at the various institutions and beyond. The teaching and learning provision can also be tailored to fulfil the needs of different student groups especially the underrepresented. The key messages from this presentation and discussion are as follows: faculty need to encourage students to be aware of their responsibility to take charge of their independent learning but also acknowledge the need for student support to develop the required skills; curriculum need to be intentionally developed to increase employability skills of all students since it is a gateway to the world of work; and faculty need to embrace change and currency as a positive response to the funding challenges of our times. This paper concludes that while we train students to acquire the skills of 
acknowledging their obligation to be proactive through their academic programs, faculty must also have their students' employability in mind. We encourage faculty to embrace all their students as the center of their professional progress and continuously view student performance as a measuring stick of faculty growth and development. As stated earlier, the income and opportunity gaps that exist in the United States and the world, increases the equalizing power of effective education. It follows that an implementation of the four components of the model developed in this paper will increase the number of underrepresented and low-income students in colleges and universities of our nation and the world.

\section{Conclusion}

As has been demonstrated in this paper, a great faculty should develop relations with their students to build trust. They should be patient, caring, and have a kind personality. With training, faculty develop skill sets that incorporate knowledge of the cognitive, social and emotional development of their students. Research shows that faculty that acquire these skill sets love teaching and are passionate about their profession and committed to their students' success. They are always willing to help students and give their time. They motivate students to succeed in and outside the classroom. The model developed in this paper advocates the use of a holistic and collaborative approach to increase the academic success by teaching all students in their classrooms. The model suggests that engaging all our students, communicating purposely to all of them, designing comprehensive support services as identified above in part 1; establishing six groups of stakeholders to collaborate in a living curriculum that bridges theory and practice and strengthens said curriculum as explained in part 2; administering continuous assessment of student progress by embracing flexibility for learning; intentionally creating opportunities in the classrooms to meet students where they are; rethinking high and low stakes assessment to help students to demonstrate mastery thus guaranteeing excellence with empathy as highlighted in part 3 and as advocated in part 4 , we must make the celebration of student progress highly visible. It encourages the involvement of the collaborative team forged in part 2 in such celebrations thus owning each student's milestones. Examples include celebrating student of the month, faculty of the month, staff of the month, and community business participant of the month. These collaborative celebrations build trust and forge greater joint efforts that increase enrollment, retention, and graduation rates.

We encourage faculty to reimagine teaching and learning by seizing the moment. A keyway to achieve this is by focusing on lessons learned from the covid-19 experience. This is the time for faculty to perfect the art of teaching and learning recognizing that change only comes when they demand it. However, faculty need to be ready to institutionalize such change thereby guaranteeing progress and ultimate increase in academic success. We can do this. During the Spring 2020 what did we learn from the covid19 pandemic? Faculty adapted and modified their syllabus; faculty was willing to train and they gained new skills; faculty humanized teaching and learning by being flexible and patient with their students. This paper needs faculty to be aggressive in seizing the moment by increasing the composition of students that succeed and graduate. If this momentum continues and is sustained, faculty would have succeeded in teaching all our students. Further research is needed to determine the impact of intentionality, inclusivity and flexibility in assessing academic success of all enrolled students.

\section{References}

Adelman, C. (2006). The Toolbox revisited: Paths to degree completion from high school though college. U.S. Department of Education. Washington, D.C: Office of Vocational and Adult Education.

American College Testing Program (ACT) 2006.

Anoopkumar, M., \& Rahman, A. M. J. M. Z. (2016). A Review on Data Mining techniques and factors used in Educational Data Mining to predict student amelioration. In 2016 International Conference on Data Mining and Advanced Computing (SAPIENCE), (pp. 122-133).

Asif, R., Merceron, A., Abbas, S., \& Ghani, N. (2017). Analyzing undergraduate students' performance using educational data mining. Computers in Education, 113, 177-194.

Asif, R., Merceron, A., \& Pathan, M. K. (2015). Predicting student academic performance at degree level: A case study. International Journal of Intelligent Systems and Applications, 7(1), 49-61.

Astin, A.W. (1993). Whatmatters in college:Four critical years revisited. San Francisco: Jossey-Bass 
Bailey, T.R., \& Leinbach, D.T. (2005). Is student success considered institutional failure?? The accountability debate at community colleges. New York, NY: Community College Research Center, Teachers College, Columbia University

Bailey, T., Jaggars, S., \& Jenkins, D. (2015). Redesigning America's community colleges: A clearer path to student success. Cambridge, MA: Harvard University Press.

Bauman, G. L., Bustillos, L.T., Bensimon, E.M., Brown, M.C., \& Bartee, R.D. (2005). Achieving Equitable Educational Outcomes with All Students: The Institution's Roles and Responsibilities. AAC\&U/Ford Foundation.

Baum, S., \& Payea, K. (2004). Education pays: The benefits of higher education for individuals and society. Washington, DC: The College Board.Bensimon 2004

Bensimon, E.M., Dowd, A.C., \& Witham, K. (2016). Five principles for enacting equity by design. Diversity \& Democracy, 19(1).

Brame, C. J. (2019). Inclusive teaching: Creating a welcoming, supportive classroom environment. In Science teaching essentials: Short guides to good practice (pp. 3-14). San Diego: Elsevier/Academic Press.

Calvet Liñán, L., \& Juan Pérez, Á. A. (2015). Educational Data Mining and Learning Analytics: differences, similarities, and time evolution. International Journal of Educational Technology in Higher Education, $12(3), 98$.

Center for Community College Student Engagement. (2013). A matter of degrees: Engaging practices, engaging students (High-impact practices for community college student engagement). Austin, TX: The University of Texas at Austin, Community College Leadership Program.

Chen, X. (2015). STEM attrition among high-performing college students: Scope and potential causes. Journal of Technology and Science Education, 5(1), 41-59.

Dadgar, M., Venezia, A., Nodine, T., \& Bracco, K. R. (2013). Providing structured pathways to guide students toward completion. San Francisco: WestEd.

Dewsbury, B. M. (2017). Context determines strategies for "activating" the inclusive classroom. Journal of Microbiology \& Biology Education, 18(3). 18.3.66.

Dewsbury, B. M. (2019). Deep teaching: A conceptual model for inclusive approaches to higher education STEM pedagogy. Cultural Studies in Science Education. doi.org/10.1007/s11422-018-9891-z

Dutt, A., Ismail, M. A., \& Herawan, T. (2017). A systematic review on educational data mining. IEEE Access, 5, 15991-16005.

Estrada, M., Burnett, M., Campbell, A. G., Campbell, P. B., Denetclaw, W. F., Gutiérrez, C. G., ... Okpodu, C. M. (2016). Improving underrepresented minority student persistence in STEM. CBE - Life Sciences Education, 15 (3), es5.

Finley, A. \& McNair, T. (2013). Assessing underserved students' engagement in high-impact practices. Washington, DC: Association of American Colleges and Universities.

Finn, J. D., \& Rock, D. A. (1997). Academic success among students at risk for school failure. The Journal of Applied Psychology, 82(2), 221-234.

Freeman, T. M., Anderman, L. H., \& Jensen, J. M. (2007). Sense of belongingness of college freshmen at the classroom and campus levels. Journal of Experimental Education, 75, 203-220. Freire, P. (1970).

Goffee, R., \& Jones, G. (2000, September/October). Why should anyone be led by you? Harvard Business Review. Retrieved from https://hbr.org/2000/09/why-should-anyone-be-led-by-you

Haak DC, HilleRisLambers J, Pitre E, Freeman S (2011). Increased structure and active learning reduce the achievement gap in introductory biology. Science 332, 1213-1216.

Hamoud, A. K., Hashim, A. S., \& Awadh, W. A. (2018). Predicting Student Performance in Higher Education Institutions Using Decision Tree Analysis. International Journal of Interactive Multimedia and Artificial Intelligence, in Press, 1.

Hearn, J.C. (2006). Student success: What research suggest for policy and practice. Paper presented at the National Symposium on Postsecondary Student Success. Available, https://nces.ed.gov/npec/pdf/synth_Hearn.pdf

Hearn, J. C. (2015). Outcomes-based funding in historical and comparative contexts. The Lumina Foundation. Available, www.luminafoundation.org/files/resources/hearn-obf-full.pdf

Henderson, S.E. (2008). Admissions' evolving role: From gatekeeper to strategic partner. In B Lauren (Ed.), The College Admissions' Officer's Guide (pp. 1-22) Washington, D.C.: American Association of Collegiate Registrars and Admissions Officers.

Hurtado, S., Alvarez, C. L., Guillermo-Wann, C., Cuellar, M., \& Arellano, L. (2012). A model for diverse learning environments: The scholarship on creating and assessing conditions for student success. In J. C. Smart \& M. B. Paulsen (Eds.), Higher education: Handbook of theory and research (Vol. 27, pp. 41-122). New York, NY: Springer.

Kuh, G. D., Kinzie, J., Buckley, J. A., Bridges, B. K., \& Hayek, J. C. (2006). What matters to student success: A review of the literature commissioned report for the National Symposium on postsecondary student success. University of California and F. Foundation for Open Access Statistics. 
Kuh, G.D. (2016). Making learning meaningful: Engaging students in ways that matter to them. In M. Watts (Ed.), Finding the why: Personalizing learning in higher education. New Directions for Teaching and Learning, No.145. San Francisco: JosseyBass.

Kuh, G., O'Donnell, K., \& Reed, S. (2013). Ensuring quality \& taking high-impact practices to scale. Washington, D.C.: Association of American Colleges and Universities.

Moira Cachia, Siobhan Lynam \& Rosemary Stock (2018) Academic success: Is it just about the grades? Higher Education Pedagogies, 3:1, 434-439, DOI: 10.1080/23752696.2018.1462096

Martins, M. P. G., Miguéis, V. L., Fonseca, D. S. B., \& Alves, A. (2019). A data mining approach for predicting academic success - A case study, (pp. 45-56). Cham: Springer.

Maton, K. I., Beason, T. S., Godsay, S., Sto. Domingo, M. R., Bailey, T. C., Sun, S., \& Hrabowski, F. A. (2016). Outcomes and processes in the Meyerhoff Scholars program: STEM PhD completion, sense of community, perceived program benefit, science identity, and research-self-efficacy. CBE-Life Sciences Education, 15, ar48.

Mohamed, M. H., \& Waguih, H. M. (2017). Early prediction of student success using a data mining classification technique. International Journal of Science and Research, 6(10), 126-131.

Muijs, D., \& Reynolds, D. (2011). Effective teaching. Evidence and practice. London: Sage.

National Center for Public Policy and High Education 2005

Pascarella, E. T., \& Terenzini, P. T. (2005). How college affects students (Volume 2): A third decade of research. San Francisco, CA: Jossey-Bass.

Perez, T., Cromley, J. G., \& Kaplan, A. (2014). The role of identity development, values, and costs in college STEM retention. Journal of Educational Psychology, 106(1), 315-329.

Pérez, B., Castellanos, C., \& Correal, D. (2018). Predicting student drop-out rates using data mining techniques: A case study, (pp. 111-125). Cham: Springer.

Purdie, J. R., \& Rosser, V. J. (2011). Examining the academic performance and retention of first-year students in living-learning communities and first year experience courses. College Student Affairs Journal, $29(2), 95$.

Reardon, S. F. (2011). The widening academic achievement gap between rich and poor: New evidence and possible explanations. In G. J. Duncan \& R. J. Murnane (Eds.), Whither opportunity? Rising inequality, schools, and children's life chances (pp. 91-115). New York: Russell Sage Foundation.

Reardon, S.F. (2013). The widening income achievement gap. Educational Leadership, 70(8), 10-16.

Reason, R. D., Terenzini, P. T., \& Domingo, R. J. (2006). First things first: Developing academic competence in the first year of college. Research in Higher Education, 47(2), in press.

Schinske, J. N., Perkins, H., Snyder, A., \& Wyer, M. (2016). Scientist Spotlight homework assignments shift students' stereotypes of scientists and enhance science identity in a diverse introductory science class. CBE-Life Sciences Education, 15(3), ar47.

Strayhorn, T. L. (2015). Cultural navigation and college student success: What works for ensuring academic excellence (CHEE \#What Works Report Series 2015-001). Columbus, OH: Center for Higher Education Enterprise, The Ohio State University.

Terenzini, P. T., and Reason, R. D. (2005, November). Parsing the first year of college: A conceptual framework for studying college impact. Paper presented at the annual meeting of the Association for the Study of Higher Education, Philadelphia

Thelin, J. R. (2011). A history of American higher education (2nd ed.). Baltimore, MD: Johns Hopkins University Press.

Valant, J., \& Newark, D. A. (2016). The Politics of Achievement Gaps: U.S. Public Opinion on Race-Based and Wealth-Based Differences in Test Scores. Educational Researcher, 45, 331-346.

https://doi.org/10.3102/0013189X16658447

Willems, J., Coertjens, L., Tambuyzer, B., \& Donche, V. (2019). Identifying science students at risk in the first year of higher education: the incremental value of non-cognitive variables in predicting early academic achievement. European Journal of Psychology of Education, 34(4), 847-872.

Wilson, D., Jones, D., Bocell, F., Crawford, J., Kim, M. J., Veilleux, N., ... Plett, M. (2015). Belonging and academic engagement among undergraduate STEM students: A multi-institutional study. Research in Higher Education, 56(7), 750-776.

Witham, K, Malcom-Piqueux, L., Dowd, A.C., \& Bensimon, E.M. (2015). America's Unmet Promise: The Imperative for Equity in Higher Education. Washington, DC: Association of American Colleges and Universities.

York, T.T., Gibson, C., \& Rankin, S. (2015). Defining and measuring academic success. Practical assessment, research and evaluation, 20 (5), 1-20. [Google Scholar]

Zumbrunn, S., McKim, C., Buhs, E., \& Hawley, L. R. (2014). Support, belonging, motivation, and engagement in the college classroom: A mixed method study. Instructional Science, 42, 661-684. 